\title{
Transatlantica
}

Revue d'études américaines. American Studies Journal

\section{Worlds within Worlds: Audiences, Jargon, and North American Comics Discourse}

\section{Craig Fischer}

\section{(2) OpenEdition}

1 Journals

\section{Édition électronique}

URL : https://journals.openedition.org/transatlantica/4919

DOI : $10.4000 /$ transatlantica.4919

ISSN : $1765-2766$

Éditeur

Association française d'Etudes Américaines (AFEA)

\section{Référence électronique}

Craig Fischer, «Worlds within Worlds: Audiences, Jargon, and North American Comics Discourse», Transatlantica [En ligne], 1 | 2010, mis en ligne le 28 septembre 2010, consulté le 10 février 2023. URL : http://journals.openedition.org/transatlantica/4919; DOI : https://doi.org/10.4000/transatlantica. 4919

Ce document a été généré automatiquement le 10 février 2023.

Creative Commons - Attribution - Pas d'Utilisation Commerciale - Pas de Modification 4.0 International - CC BY-NC-ND 4.0

https://creativecommons.org/licenses/by-nc-nd/4.0/ 


\title{
Worlds within Worlds: Audiences, Jargon, and North American Comics Discourse
}

\author{
Craig Fischer
}

1 Let me begin by describing four recent acts of comics criticism, all connected to each other like dominoes falling:

2 The first act: In 2007, the University Press of Mississippi published an English-language translation of Thierry Groensteen's The System of Comics (Système de la bande dessinée, 1999). In their foreword to System, translators Bart Beaty and Nick Nguyen anticipate obstacles to the American reception of Groensteen's ideas, arguing that American scholars are unfamiliar with the "dominant schools of visual analysis" (viii), most notably semiotics, that inform Groensteen's approach. Additionally, Beaty and Nguyen point out that some of examples Groensteen brings up come from international artists whose works remain unknown in the United States. As Beaty and Nguyen write, "To call E.P. Jacobs a 'wordy' cartoonist is one thing, but for readers who have not been raised on a diet of Blake and Mortimer albums, the specificity of this off-hand comment may well be lost" (ix). Personally, I recognized many of Groensteen's examples; I own a translated version of the Blake and Mortimer adventure The Time Trap ${ }^{1}$, so I know how text-heavy Jacobs' comics are. Also, Groensteen cites several English-language comicsAlan Moore and Dave Gibbons' Watchmen (1987), for instance, and "The Plot Thickens," a Bill Griffith strip from Raw \#2 (1980)-that I and other American comics readers would recognize.

3 The second and third acts: Two reviews of the English-language System appeared in The Comics Journal \#284 (July 2007). The first reviewer, critic and teacher Leonard Rifas, begins by accusing Beaty and Nguyen of elitism. Rifas calls Beaty and Nguyen's claim that part of System's difficulty for U.S. readers lies in Groensteen's use of unfamiliar textual examples a "preemptive insult," since it implies that "if you fail to be moved by this superlative work, this must be because of your own lamentable ignorance" (99). After summarizing some of Groensteen's arguments (his survey of previous definitions 
of the comics medium, and his coining of concepts like "spatio-topia" and "arthology"), Rifas concludes by accusing Groensteen of academic obfuscation, writing that System appears to offer the insufficiently prepared reader an unnecessarily opaque way to explore such simple ideas as the fact that when you open a book you see two pages at the same time or that a comic can tell stories without using words or that speech balloons usually but not always consist of white shapes surrounded by lines. From the perspective of European neo-semiotic analysis, American comics scholarship can seem underwhelming, but the feeling can be mutual. (100)

4 Rifas sums up System as "188 pages of tough, dry slogging" (100). The second review, by Journal regular Bill Randall, is much more complimentary. While admitting that Groensteen's terminology “does not sing in English” (102), Randall praises System's focus on comics as a nested form of aesthetic organization: "Not limited by time, [comics] can make connections across pages or even leaping from page to page, just by spatial resonances" (102). According to Randall, concepts like these "will influence a generation of English-speaking comics scholars" (102).

5 My own reaction to system falls between these two extremes. Initially, I found Groensteen's prose and jargon difficult to navigate, but when I applied System's concepts to a specific example, a page of blank panels from Jason's Hey, Wait (2001), I found them extremely useful (Fischer). (Like Randall, I was particularly impressed with Groensteen's description of the comics medium as a kind of reverse Matryoshka doll, where the smallest unit of signification, the panel, can connect and rhyme with larger structures like the tier, the page, the double-spread, and even the "multiframe" of the entire comic or book.) Still, I'd guess that any American comics reader who's tried to read Groensteen has responded with the same exasperation as Rifas. During a recent presentation at a comics convention, I applied Groensteen's multiframe idea to the Harvey Kurtzman/Wally Wood Mad story "3-Dimensions!" (1954), and an audience member asked me who Groensteen is and how to spell his name. After I replied and mentioned system, one of my fellow panelists commented that they found system about as entertaining as reading "an operation manual for a new lawnmower." Dry slogging is the consensus.

The fourth act: At the International Comic Arts Forum meeting in Washington D.C. in October 2007, veteran comics scholar Joseph Witek presented a paper titled "American Comics Criticism and the Problem of Dual Address." Witek's paper was subsequently published in The International Journal of Comic Art. The "dual address" in Witek's title refers to the tendency of English-language comics scholars to aim their writing simultaneously at two (or more) very different audiences, including other comics scholars, and a broader readership comprised also of artists and fans. According to Witek, this dual address has watered down American comics studies, preventing the discipline from cohering into "a real and advancing dialogue" (223), and the controversial American reception of The System of Comics is a symptom of the problem.

7 Witek argues that Beaty and Nguyen are wrong to claim that Groensteen's examples are the central reason why System is tough reading for American fans and scholars. Rather, Witek writes that "an even greater difficulty for the audience lies in the degree to which Groensteen's entire critical project is implicated in an existing scholarly discourse" (221). Groensteen's engagement with the European "scholarly discourse" on comics is not just difficulty-for-difficulty's-sake, but represents academic common sense: 
At least some academic discourse can, in fact must, be addressed to those readers who are themselves generating the discourse in the field, and the deployment of specialist vocabulary can be essential to the creation of new disciplinary knowledge. (221)

Witek reads Rifas' hostility to System, then, as justified but misguided. Rifas rightly believes that Groensteen's jargon excludes him from the discussion, but that doesn't mean that the jargon is, to use Rifas' word, "gibberish" (100). For Witek, System's terminology represents the generation "of new disciplinary knowledge," and Rifas' exclusion comes as a side-effect of his lack of expertise in semiotics and other European theoretical traditions. There are only a handful of American comics scholars with the expertise to navigate Groensteen's concepts and terminology, and I felt excluded myself because I'm not one of those scholars. I fought hard-re-reading System twiceto understand some, though certainly not all, of Groensteen's ideas.

While I find myself sympathetic to Witek's point of view, I want to challenge and clarify at least two of the assumptions he makes in "American Comics Criticism and the Problem of Dual Address." First is the notion of "dual address," a vague phrase that fails to identify either the various discursive communities in American comics culture or the various ways in which the communities interact and overlap. Witek does acknowledge that there are more than two such communities; he characterizes American comics studies, for instance, as work written for "an imperfectly imagined hangman's jury of deans, intra- and extra-disciplinary experts, the editors and readers of the Comics Journal, and the people who write book reviews on Amazon.com, all of these with divergent discursive expectations and often contradictory goals" (219). To track more precisely these expectations and goals, however, I'll borrow and adapt a rubric from film scholar David Bordwell to place comics' discursive communities into three (rather than two) broad categories, and then argue for the advantages, as well as the disadvantages, to reading and writing across boundaries. Another major subject of debate in the Beaty-Nguyen-Rifas-Witek conversation is the need for specialized vocabulary in comics scholarship-or, for that matter, in any scholarship-and I believe in a middle ground between Witek's claim that new terminology is sometimes necessary to present new disciplinary information and Rifas' dismissal of jargon as "gibberish." Let me consider each topic in turn.

\section{Norms}

10 In the second chapter of his 1989 book Making Meaning: Inference and Rhetoric in the Interpretation of Cinema, David Bordwell contends that there are three dominant types of writing about film: journalistic criticism, published in newspapers and general-interest magazines, and offering a quick evaluation of which movies to see and which to avoid; essayistic criticism, published in specialty magazines (Film Comment, Cahiers du cinéma) and focused on longer, more in-depth coverage of auteurs, genres and national cinemas; and scholarly criticism, published in academic venues like Cinema Journal, buttressed by citations and bibliographic information, and aimed at a highlyspecialized audience of teachers and researchers (20). Bordwell presents this list as part of his attempt to define what critical interpretation-of movies, comics, any type of culture-involves, and his take on the essence of interpretation is surprising. Arguing 
against Roland Barthes' contention that interpretation is an inherently complex and "writerly" practice, Bordwell writes:

I do not share Barthes' suspicion that "reading" [i.e. interpretation] is an irreducibly heterogeneous activity. Interpretation is one of the most conventional things that film critics do. Even when a critic purports to produce an "unconstrained" interpretation, he or she will not only use standard strategies but will very likely generate a highly routinized reading, rather as the improvising pianist will often fall back into the most banal tunes and chord progressions. (40) Groening cartoon to lay bare "the conventionality of film reviewing" (36):

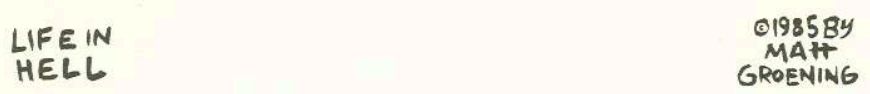

\section{HOW TO BE A CLEVER FILM CRITIC}

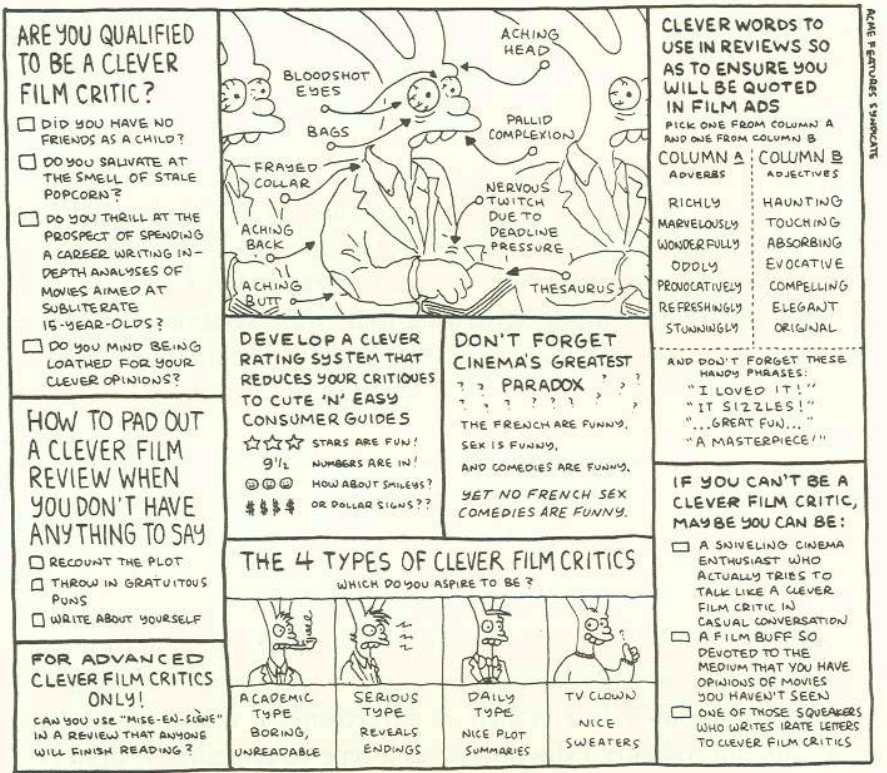

III. 1

12 We all recognize the rules that clever film critics follow, which is Bordwell's point. Though the films themselves may be "stunningly original" (or, more likely, not) the critics' ways of interpreting them are formulaic and thoroughly conventional. Throughout Making Meaning, Bordwell exposes the formulas, and encourages critics of all kinds-journalistic, essayistic and scholarly-to set off in new directions. The final chapter of Bordwell's book is called "Why Not to Read a Film."

\section{Fans}

Are there similar norms and formulas in comics criticism? I see a taxonomy similar to Bordwell's in American writing about comics, with fan appreciation, essayistic criticism and academic criticism as the dominant modes of interpretation. The central purpose of fan appreciation is to extend the enjoyment a reader gets from the comics themselves; while this sometimes can be evaluative-fans write reviews to steer other fans away from bad comics, or castigate a company's mistreatment of a beloved character-the 
tone of fan appreciation is usually celebratory. The most frequent rhetorical trope of fan appreciation is what we might call the "origin story," where a writer nostalgically muses on the first time s/he read and fell in love with comics or fandom. Several of today's most renowned alternative cartoonists, for instance, talk about Harvey Kurtzman's work as an epiphanic bolt-from-the-blue. For Robert Crumb, various issues of the Kurtzman-edited Mad were revelations. From "Ode to Harvey Kurtzman," collected in The R. Crumb Coffee Table Art Book (37):
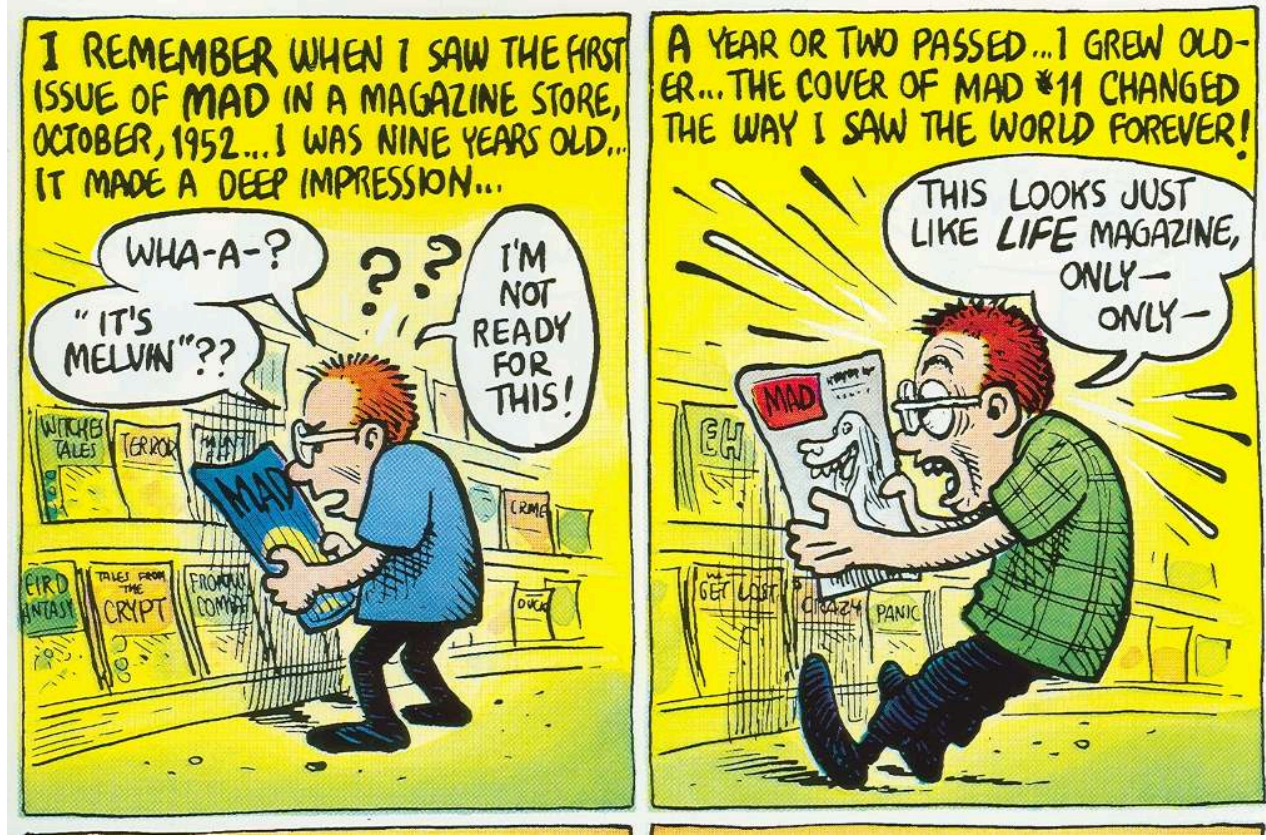

III. 2

Mainstream American comics fans likewise tell origin stories. At the conclusion of The Golden Age of Comics Fandom, Bill Schelly describes a series of "indelible memories" associated with the Lost Paradise of comics fandom of the 1960s:

The sight of the cover of a latest issue of your favorite fanzine, as it slid out of its manila envelope; the smell of a rare, old comic book as you opened your first artifact from the 1940s; the thrill of the first time you met a comics pro.

Comicdom back then was coins taped to letters...fingers smudged purple from ditto masters...the smell of spirit duplicator fluid...poring over comics ads in RB-CC [The Rocket's Blast-Comicollector, an early fanzine]...mailing off orders with four and five cent stamps.

Trips to the mailbox were a daily adventure. The mails brought wondrous gifts: comics, letters, original art.

The particular innocence of the Golden Age of comic fandom is gone forever, as is our own. There's no passage back to that simpler time. Except, perhaps, through the pages of the classic fanzines. (162)

Beyond the origin story, another common way to relive the early pleasures of comics and fandom is through fan fictions, where fans write new stories about their favorite characters and the fictional worlds these characters inhabit. Fan fictions are closely connected to fan interest in continuity, in the consistency and history of the diegetic "universes" created by particular comics companies, and fan writing on continuity can be dauntingly complex. In the 1970s fanzine OMNIVERSE: The Journal of Fictional Reality, editor Mark Gruenwald and other fans discussed parallel dimensions in almost encyclopedic detail (see Robertson for more information on Gruenwald and 
OMNIVERSE), and these discussions continue on the Internet today, with the blogger "Siskoid" being perhaps the most sophisticated contemporary commentator on comics' fictional worlds. (I've included three of Siskoid's blog posts on continuity in the bibliography.)

One subsection of fan appreciation is investment fandom, where comics are cherished for their monetary value rather than their stories. The predatory prozine Wizard includes a price guide for "hot" comics in every issue, and perhaps the ultimate expression of investment fandom is the service provided by the Certified Guaranty Company (www.cgccomics.com), who will, for a price, grade the condition of one of your comic books (on a scale from Gem Mint to Poor) and "encapsulate" it in a plastic sheath designed to keep it in optimal condition forever. Encapsulation means, of course, that you'll never be able to read the comic again unless you shatter the plastic, let the Benjamin-esque aura leak out, and ruin the comic's value. Even if you're illiterate, you can still be a comics collector.

\section{Essayists}

The second dominant mode of American comics writing is essayistic criticism, and the long-lived exemplar here is The Comics Journal. The Journal is probably best known for their long interviews with individual creators that run the gamut from contemporary mini-comics cartoonists to artists active in the early days of comics, like Gil Kane, Pierce Rice and Creig Flessel. These interviews with older creators might be the Journal's greatest public service; in addition to preserving the stories of these creators before they pass on, these interviews revealed to me that the eminently disposable medium of comics had a history worth celebrating and researching. There are others conducting historically significant interviews-in Alter Ego, Jim Amash is seemingly devoted to hunting down and interviewing everybody who's worked in comics since Action \#1-but the uninterrupted 30+ year publication of the Journal makes it the primary source of American comics historiography.

Besides the interviews, the Journal is best known for its review section, and its reviewers are a diverse lot who nonetheless produce writing that adheres to a few general interpretive norms. (Full disclosure: I've written for the Journal since 2001, and my name is on the masthead as a contributor.) The typical Journal review is a personal essay, often with some autobiographical content, that rigorously evaluates a comic or comics-related book. One model for this type of essay is the work of the American "public intellectuals" of the mid-1950s, described by Phillip Lopate thusly:

In magazines such as Partisan Review and Commentary, a more combative, energetic, pushy style of essay writing was coming to the fore. The postwar era saw the ascent of the essayist as public intellectual, invited to take stands on just about everything from politics to culture to the personal life. In retrospect, the oft-abused fifties now look like a golden age of American essay prose, with such writers as Mary McCarthy, Edmund Wilson, Lionel Trilling, Harold Rosenberg, Robert Warshow, Irving Howe, Elizabeth Hardwick, Alfred Kazin, Leslie Fiedler, James Baldwin, Seymour Krim, and Gore Vidal. Since then, fewer essayists have had the confidence or the nerve to offer themselves as all-purpose, generalist commentators. Some would attribute this to an erosion of the public, civic sphere. Others would point to the greater faith the public now places in experts-which may indeed account for the proliferation of essay collections by physicists, surgeons, biologists, animal trainers, and literary theorists. $(x l v x)$ 
19 This is exactly the tradition that Journal editor Gary Groth has repeatedly praised in articles and interviews, as in a 2003 interview with Ana Merino where Groth lists as his inspirations the 1960s "flowering of film criticism" ("Kael, Simon, Kaufman, Sarris, MacDonald, Young, and then before them, Agee, Ferguson and others") and various writers for Partisan Review, including Howe, McCarthy, Lionel Trilling, Diana Trilling, and Gilbert Sorrentino (Merino 43). Lopate sees a shift in the American personal essay from generalist commentators to experts; in editing the Journal's review section, Groth welds the "combative," ferociously erudite prose style of the public intellectuals to the comparatively narrow field of comics.

Absolutely central to Groth's image of the Journal is his emphasis on evaluative reviews. In the 2003 interview, Groth denounces academics for their reluctance to make critical distinctions, which leads to the following heated exchange between Groth and Ana Merino:

Groth: Academia doesn't cultivate unique voices that have distinctive perceptions of the work they scrutinize: they more and more specialize in value neutral "analysis," wholly removed from qualitative distinctions. Instead of learning the virtues a critic believes a work possesses, you know how he applied or imposed certain theories.

Merino: Sometimes there is an enjoyment for the art per se. And you don't have to focus on, say, if it is good or bad.

Groth: It's crucial. That's crucial.

Merino: No it's not.

Groth: Well, that is the perfect academic point of view.

Merino: In the moment you choose to work about something, there is a value. It is why you choose to work on that. If it wasn't of any value you will not choose it.

Groth: Sorry, your underlying presupposition is fallacious. The academy often analyzes work of no evident value whatsoever. (44-45)

Given Groth's animus for academia and his emphasis on "qualitative distinctions," it's no surprise that the Journal's reviews are written in a conversational style, and typically offer some sort of thumbs-up/thumbs-down judgment on the work under scrutiny. Various newer sources of essayistic criticism, however, have tried to deemphasize evaluation in favor of more analysis. The magazine Comic Art specializes in career profiles, intricate close readings, numerous illustrations, and an unspoken assumption in the worth of their subjects ("If it wasn't of any value you will not choose it"), while Comic Art contributor K. Parille, in a recent blog posting, advocated "an approach to reading in which the critic focuses on explanation over judgment" (Parille).

As a contributor to the Journal, my problem with Groth's emphasis on evaluation is the absence of communal standards. In the editorial to Journal \#100 (July 1985), Groth reprinted a commentary from the British fanzine BEM where Bernard Leak pointed out that despite the Journal's commitment to excellence, "muscular standards-raising activity requires some kind of focus, some general agreement on what a good comic is; and there isn't any such agreement, in the pages of the Journal or anywhere else" (Groth 12). Leak further argued that

A general theory of comics, such as has been produced (in many conflicting forms, of course) for literary genres like novels and epics, is necessary before any dreams for the future can take on a definite shape and positive content. If someone doesn't like any particular theory, he can supplement, modify or replace it; but until one appears all criticism of comics will be floating in the void, unsupported by anything more than a consensus of some readers' uncontrolled intuitions. (12) 
Hindsight is 20/20: the quality of American comics has risen since 1985, but Fantagraphics' aggressive publishing and promotion of artists like Chris Ware and Joe Sacco had more to do with the rise of the graphic novel than any theoretical consolidation in the Journal. Over a decade later, in his editorial for Journal \#200, Groth can only define comics criticism in amorphous terms: "In order to truly appreciate art, you need enough distance to stand outside of it, but not so far outside as to make yourself remote from its particular beauty. It has to touch you impersonally. (Get too close and you'll start crying at Love Story.)" (6). I love the Journal and I'm grateful for the chances I've had to publish there, but I also lament that transformative interpretive concepts haven't arisen from its pages in the same way that la politique des auteurs emerged from Cahiers du cinema to influence the broader culture. Given Groth's hatred for academia, it's ironic that the Journal is in the same situation as Witek sees in academic comics writing: in a theoretical vacuum, without a tradition of scholarship to tap into and develop.

\section{Scholars}

The norms of academic comics discourse are much the same as the norms of other types of academic writing. Groth's claim that academic writing applies or imposes "certain theories" is, to my view, fairly accurate; most scholarly articles on comicsincluding this one-either present a new theory or import an established theory from another discipline (like film studies), and then apply said theory to an individual text or texts in question. This two-part heuristic runs the risk of being, quite bluntly, crushingly boring. In his book The Avant-Garde Finds Andy Hardy, Robert Ray argues that although critical theory supposedly overthrew New Criticism's emphasis on close reading, critical theory still behaves the same way as New Criticism, since both do routinized dissections of single texts. Ray characterizes the situation in film studies for instance, by noting that the "typical title in film studies has become 'Barthes, Brecht, Bakhtin, Baudrillard, and all those other people, and Robocop"' (5). The typical title in American comics studies would be "Scott McCloud, and Not So Many Other People, and Fill in the Blank with a Comic of Your Choice."

Witek argues that the central difference between European and American comics scholarship is that the Europeans, particularly the French, have developed a body of theory that scholars in the field rely on to go deeper in their observations about the medium. We Americans don't have this theoretical history because we suffer from a lack of concrete institutional support. Many of the academic comics institutions in America are in precarious shape. The International Journal of Comic Art is published, essentially, by one man-the insanely prolific and hard-working John Lent of Temple University-and some university libraries refuse to order IJOCA because it's not published by an academic press. The main American graduate program in comics studies, at the English department at the University of Florida at Gainesville, is likewise linked to the efforts of a single scholar, Donald Ault, and both Lent and Ault are over retirement age. I worry about the future of both IJOCA and the Florida program (including its online journal ImageTexT, and its yearly UF Comics Conference, which has been fitfully publicized over the last few years) when both men step away from their grueling responsibilities. Meanwhile, comics conferences struggle with their own challenges-the Comics Arts Conference is lost in the million-ring circus of the San 
Diego Comicon, while the International Comic Arts Forum struggles every year to raise money to pay for the expenses of overseas guests. (Full disclosure \#2: I served on the ICAF Executive Committee for three years, from 2004 to 2007.) On an individual level, most so-called "comics scholars," including many of the contributors to this issue of Transatlantica (Bart Beaty, Charles Hatfield, myself), are actually laborers in other fields (literature, film studies) who carve out time in their research agendas for comics.

To be sure, the last twenty years have seen impressive American monographs in comics studies, pioneered by Witek's own Comic Books as History: The Narrative Art of Jack Jackson, Art Spiegelman and Harvey Pekar (1990), a book that I treasure most for its scholarly, meticulous close readings of panel and page layouts. Other notable books include Amy Kiste Nyberg's Seal of Approval: The History of the Comics Code (1998), an intricate historical survey of the 1950s American "comics crisis"; Hatfield's Alternative Comics: An Emerging Literature (2005), simultaneously a study of a movement and the major artists (particularly Gilbert Hernandez) that comprise that movement; and Beaty's Unpopular Culture: Transforming the European Comic Book in the 1990s (2006), a Bourdieu-ian take on such contemporary European alt-cartoonists as Fabrice Neaud, Lewis Trondheim and David B. (The fact that Neaud, Trondheim and David B. are known in the U.S. at all is because of Beaty's relentless attention to their comics in scholarly texts like Unpopular Culture and in journalistic writing like his long-running column "Eurocomics for Beginners," currently carried on Tom Spurgeon's Comics Reporter site.)

There has been progress, but there could have-should have-been many more books. Until universities respect comics enough to hire tenure-track faculty whose central job is to teach and write about comics, and until scholars convince universities and scholarly organizations to put money and in-kind support into a network of conferences and journals, we'll be hard-pressed to develop a body of theory as sophisticated as the European model.

\section{Jargon, Boundaries, Transgressions}

In place of Witek's idea of dual address, then, I'd identify at least three different modes of address-fan appreciation, essayistic criticism and academic criticism-and at least two of these modes use jargon to create a sense of connection between writer and audience. Due to the overwhelming influence of Groth and the Journal, American essayistic criticism on comics is relatively jargon-free, but comics collectors and fans have long cultivated their own specialized vocabulary (words and phrases like "Silver Age," "headlights" and "splash page" befuddled me when I first started collecting comics) ${ }^{2}$, and we've already identified how Rifas, primarily an essayistic critic, despises Gronesteen's lit-crit prose and jargon.

I understand Witek's point that jargon is sometimes necessary in the presentation of new, discipline-specific knowledge, and I can also appreciate how jargon can create an identity and a lingua franca for a small, focused community. As Walter Nash writes, jargon "helps to sustain the fabric of society-so effectively that it seems at times to be the fabric, and everything else mere pattern and colouring. In its simplest function it marks the dealings of professionals who share a calling, as they explain positions, expound arguments, signify agreement, banter with each other. We have workmates; jargon is a token of mateship" (96). Every "signification" we interpret and multiframe we dissect brings us comic scholars closer together. 

part attributable to my early education; in at least three classes in high school, I read George Orwell's canonical essay "Politics and the English Language," and took to heart Orwell's fear of pretentious diction and obfuscating figures of speech. In his essay, Orwell defines political speech as insidious because of how it cloaks truth, as in this euphemistic example: "Defenceless villages are bombarded from the air, the inhabitants driven out into the countryside, the cattle machine-gunned, the huts set on fire with incendiary bullets: this is called pacification" (173). The stakes are considerably lower in comics studies, of course, but it's no stretch to say that there are plenty of academic articles where the author uses diction that is unnecessarily high-brow in order to impress the reader with false "erudition." Jargon also serves as an instrument of social distinctions, as a way of asserting insider status and upholding doctrinal boundaries: I know the insider vocabulary, so I'm a comics fan and/or comics academic and you're not. At one point in "American Comics Criticism and the Problem of Dual Address," Witek acknowledges that "contemporary academic discourse in the humanities can be as turgid and unlovely as it is obtuse, which finally is simply to say that bad work is bad, whether it is couched in the vocabulary of theory or not" (223), which for me begs the question: if you have something worthwhile to say, should you write it in "turgid" and "obtuse" prose, or in writing designed to convey your message to the broadest possible audience?

fears that simplifying our language will involve dumbing down our ideas, and he's quite right in his impulse to uphold academic standards. If forced to choose between jargon-with-good-ideas vs. clear-writing-with-watered-down-ideas, I'd always opt for the former, though I suspect a clear-cut dilemma like this would be rare. In addition, I like boundary-hopping in my comics writing and comics culture more than like Witek does; it would break my heart to see a "Superman Can Beat Up the Hulk" presentation at an academic comics studies conference, but there are instances where cross-hybridization between the spheres of fan appreciation, essayistic criticism and academic criticism leads to fertile intersections and broader dissemination of new ideas about comics. One of my favorite American publications about comics is The Jack Kirby Collector (TJKC), and not only because my own "origin story" hinges on my childhood discovery of Kirby's art. Rather, I relish the way TJKC juxtaposes nerdy, fannish discussions of the first appearance of "Kirby Krackle" (that dot design so common in mid-to-late Kirby cartooning) with remarkably well-researched articles about the LeeKirby collaboration by Mike Gartland and meticulous close readings of Kirby stories by Charles Hatfield. (Might I recommend Hatfield's extended take on Mister Miracle \#9, "Himon," in TJKC \#35 [Spring 2002]?)

I've also seen comics culture diminish when cross-hybridization goes away. For many years (1997-2002, and again in 2004), the academic International Comic Arts Forum (previously the International Comic Arts Festival) partnered with one of America's premiere comics conventions for alternative creators, the Small Press Expo in Bethesda, Maryland. The organizations ended their partnership after the 2004 SPX, however, and I desperately miss the fizzy energy SPX contributed to the more intellectually rigorous, but undeniably more sedate, ICAF. I loved how SPX attendees would wander into the ICAF suite and hear comics talked about in new and startling ways; I loved how ICAF organizers were able to include Art Spiegelman and the Hernandez Brothers in panels and discussions because these creators were already 
attending SPX anyway. After the split, neither was the same and both were impoverished. The absence of ICAF's academic programming makes SPX now feel like it's more about commerce than art, and ICAF's programming suffers from its lack of access to SPX's stable of visiting artists. I wish SPX and ICAF had never divorced, and I hope that other comics communities might eschew jargon and leap past doctrinal boundaries in order to combine resources and exchange ideas. I'm simultaneously a comics fan, a Comics Journal reviewer, and an academic committed to validating comics studies as a legitimate discipline in American universities; is it too much to hope for forms of writing and conferencing that speak to more than one aspect of my multifaceted interest in comics? Is it too much to hope for an American academic discourse of comics that avoids the inherent boredom of the "Scott McCloud, and Not So Many Other People, and Fill in the Blank with a Comic of Your Choice" formula? We shall see.

\section{BIBLIOGRAPHIE}

BORDWELL, David. Making Meaning: Inference and Rhetoric in the Interpretation of Cinema (Cambridge: Harvard University Press, 1989).

CRUMB, Robert. The R. Crumb Coffee Table Art Book (New York: Back Bay Books, 1997).

FISCHER, Craig. "The System of Comics (Craig Replies)," Thought Balloonists (January 29, 2008), September 26, 2010 <http://www.thoughtballoonists.com/2008/01/the-system-of-1.html>.

GROENSTEEN, Thierry. Systéme de la bande dessinée (Presses Universitaires de France, 1999). Translated by Bart Beaty and Nick Nguyen, The System of Comics (Jackson: University Press of Mississippi, 2007).

GROTH, Gary. "A Few Scattered Thoughts on 200 Issues (or 174 to be Exact) of The Comics Journal," The Comics Journal 200 (December 1997), 3-7.

---. “Another Call to Arms," The Comics Journal 100 (July 1985), 9-12.

LOPATE, Phillip. "Introduction," in The Art of the Personal Essay: An Anthology from the Classical Era to the Present, edited by Phillip Lopate (New York: Anchor Books, 1994), xxiii-liv.

MERINO, Ana. "Gary Groth and Kim Thompson: Interviews with the Heart of the Alternative Comics Industry,” The International Journal of Comic Art 5.1 (Spring 2003), 31-73.

NASH, Walter. Jargon: its Uses and Abuses (Cambridge: Blackwell, 1993).

ORWELL, George. "Politics and the English Language," in A Collection of Essays (Garden City: Doubleday and Compnay, 1954), 162-176.

PARILLE, K. “Need-Based Criticism," Blog Flume (July 13, 2008), September 26, $2010<$ http:// blogflumer.blogspot.com/2008/07/need-based-criticism.html>.

RANDALL, Bill. "Educational System," The Comics Journal 284 (July 2007), 101-102.

RAY, Robert. The Avant-Garde Finds Andy Hardy (Cambridge: Harvard University Press, 1995).

RIFAS, Leonard. “Is Dis a System?" The Comics Journal 284 (July 2007), 99-100. 
ROBERTSON, Chris. "Mark Gruenwald, the Father of Modern Superhero Comics," Robertson's Interminable Ramble (July 2, 2007),

September 26, $2010<\mathrm{http}$ //www.chrisroberson.net/2007/07/mark-gruenwald-father-ofmodern.html>.

SCHELLY, Bill. The Golden Age of Comic Fandom. Revised Edition (Seattle: Hamster Press, 1999).

SISKOID. “Bubble World Theory in Myth Building," Siskoid's Blog of Geekery (January 7, 2008), September 26, 2010 < http://siskoid.blogspot.com/2008/01/bubble-world-theory-in-mythbuilding.html>.

---. “Let's Play with Models!” Siskoid's Blog of Geekery (January 28, 2008), September 26, 2010 <http://siskoid.blogspot.com/2008/01/lets-play-with-models.html>.

---. “Pass the Retcon, I'm Feeling Mmemonic.” Siskoid's Blog of Geekery (January 25, 2008), September 26, $2010<\mathrm{http}$ ///siskoid.blogspot.com/2008/01/pass-retcon-im-feelingmmemonic.html>.

WITEK, Joseph. "American Comics Criticism and the Problem of Dual Address," The International Journal of Comic Art 10.1 (Spring 2008), 218-225.

\section{NOTES}

1. English translation of Le Piège diabolique (Paris: Lombard-Dargaud, 1962) published in the U.S. by Comcat Comics in 1989.

2. Just to save you similar befuddlement, let me define these terms. "Silver Age" is fan jargon for 1960s superhero comics (following the "Golden Age" birth of the superhero in the late 1930searly 1940s); "headlights" is a slang term for the pointy breasts drawn on many female comics characters; and a "splash page" is a comic book page comprised of one big panel, and as such are usually reserved for moments of intense action or violence.

\section{AUTEUR}

\section{CRAIG FISCHER}

Appalachian State University 